\title{
Violence against adolescent girls: A fundamental challenge to meaningful equality
}

Judith Bruce

Population Council

Follow this and additional works at: https://knowledgecommons.popcouncil.org/departments_sbsr-pgy

Part of the Family, Life Course, and Society Commons, Gender and Sexuality Commons, and the International Public Health Commons

How does access to this work benefit you? Let us know!

\section{Recommended Citation}

Bruce, Judith. 2012. "Violence against adolescent girls: A fundamental challenge to meaningful equality," GIRLS FIRST! Perspectives on Girl-Centered Programming. New York: Population Council. 
A GIRLS FIRST! PUBLICATION

VIOLENCE AGAINST ADOLESCENT

GIRLS: A

FUNDAMENTAL

CHALLENGE TO

MEANINGFUL

EQUALITY

BY JUDITH BRUCE 


\section{GIRLS FIRST!}

\section{PERSPECTIVES ON GIRL-CENTERED PROGRAMMING}

The field of research and programs for adolescent girls has traditionally focused on sexuality, reproductive health, and behavior, neglecting the broader social and economic issues that underpin adolescent girls' human rights, overall development, health, and well-being. Further, efforts to improve girls' lives often spotlight those who control or influence their lives-parents, in-laws, boys, men, perpetrators-overlooking girls themselves.

GIRLS FIRST! Perspectives on Girl-Centered Programming is a set of five thematic Reviews, written by experts at the Population Council. They are snapshots of the knowledge base at a particular moment in this quickly changing field. They address the five strategic priorities defined in the UN Joint Statement, “Accelerating Efforts to Advance the Rights of Adolescent Girls" (March 2010), which represents the collective commitment of seven UN agencies to support governments and partners in advancing key policies and programs for the hardest-toreach adolescent girls. The Reviews therefore:

1. Explore where to go next with education for girls;

2. Outline innovative approaches to improving girls' health;

3. Reframe the field's approach to violence against girls;

4. Describe the best ways to cultivate girl leaders; and

5. Explain novel ways to collect and use data on adolescent girls.

The Reviews put forward innovative arguments for investing in girls and highlight promising practices. They express a forward-looking and evidence-based point of view on where the field must allocate resources in order to most quickly and effectively improve girls' lives.

These Reviews-while written by experts at the Population Council, an organization that has pioneered cutting-edge research and programming for vulnerable and marginalized adolescent girls-were catalyzed with leadership support from the UN Adolescent Girls Task Force. Additional moral and material support was provided by UN Women (previously UNIFEM), the Nike Foundation, the UN Foundation, and the David and Lucile Packard Foundation. These Reviews add to other programmatic guidance and tool kits now available and serve as an essential reference for anyone seeking to develop successful and sustainable policies and programs for girls. We hope that they will inspire innovative approaches in efforts that realize the rights of marginalized adolescent girls worldwide.

December 2011

Population Council and UN Adolescent Girls Task Force

Disclaimer

The Reviews on programming for adolescent girls in the areas of Education, Health, Reduction of Violence, Girls Leadership, and Data have been prepared by the Population Council for the UN Adolescent Girls Task Force (UN AGTF), with support from the United Nations Foundation, the Nike Foundation, the Packard Foundation, and UN Women.

The views expressed in these Reviews are solely those of the authors and do not necessarily reflect the views of their donor partners. 


\title{
VIOLENCE AGAINST ADOLESCENT GIRLS: A FUNDAMENTAL CHALLENGE TO MEANINGFUL EQUALITY
}

\author{
BY JUDITH BRUCE
}

\section{BASIC KNOWLEDGE AND PREMISES.}

Violence against girls: Undermining

society's promise of equality

Extreme violence affects at minimum a third of all females and a high, possibly rising, proportion of girls younger than 15

Acceptance of violence shrinks girls'

sense of self, the hours of the day, and their lives ....4

Human rights frameworks are often applied in a manner geared to the realities of dominant, particularly male, populations

Summing up: The consequences at the individual and social level of violence are so grave that prevention is the first priority.

\section{THE CURRENT LANDSCAPE}

Programs prioritize treatment and perpetrators over prevention and girls. .7

Youth programs fail to reach girls often or at all in proportion to their need

Promising research is beginning to define factors that protect girls from violence and make them more able to clearly see and manage their environment ....7

\section{PROMOTED POLICIES AND PRACTICES}

Use data to find girls at exceptionally high risk 9

Devote more resources to building protective assets of the girls at most risk 9

Use girls' knowledge to design prevention, mitigation, reporting procedures, and treatment programs

Create regularly available platforms and spaces for girls, particularly those at the highest risk of exploitation ..........10

Purposefully recruit at-risk girls.

Anchor programs with girls as the core client:

Reach out to others selectively and based on

girls' assessments

Determine which (if any) media could make

a difference based on girls' experiences...

Protecting girls as they seek justice.

Measuring results at the level of the girl
RESOURCES: LEARNING LAB PROGRAMS, PUBLICATIONS, AND TOOLS

Multilevel effort to change child marriage

norms and support married girls:

Berhane Hewan, Ethiopia

Girl spaces in school: Our girls, our future-

building synergy to end violence against

girls in Zambia

Promoting safe workspaces for women

working in bars: Tanzania

Biruh Tesfa (Bright Future): Providing

meeting spaces, skill-building, and protective assets for domestic workers, orphans, and migrants in urban Ethiopia.

Abriendo Oportunidades: "Safescaping" with a rural girls' program in Guatemala

A community contract that rejects violence:

Tostan, West Africa. .14

The Safe Cities program: The Association for the Development and Enhancement of Women, Egypt

Paraprofessional Social Work Training Program, International Rescue Committee (IRC),

Somali Region of Ethiopia

Growing Up Safe and Healthy (SAFE): Reducing the gender equality gap through gender-based violence prevention messages in Bangladesh...................15

Apne Aap: Eradicating sex-trafficking in India 15

It's All One Curriculum: A unified approach to sexuality, gender, HIV, and human rights education 


\section{BASIC KNOWLEDGE AND PREMISES}

Violence against girls: Undermining society's promise of equality

Societies, rich and poor alike, are increasingly articulating commitments that guarantee girls safe and equal access to entitlements, services, social participation, and economic opportunities. Yet threats of violence in many forms-culturally affirmed (child marriage, female genital mutilation), intimate (carried out by family members and partners), casual (carried out by strangers), and planned (trafficking)intervene to prevent girls from claiming their rights.

Many countries are signatories to the Convention on the Elimination of All Forms of Discrimination against Women (CEDAW) and the Convention on the Rights of the Child (CRC), and stipulate equality between males and females in their constitutions. Theoretically, safe access to resources and facilities is equally afforded to girls and boys, however a far higher proportion of boys and a smaller subset of usually more privileged girls may actually claim their rights and opportunities. The graphic on the right provides a general illustration of how violence impedes structural access.

Girls' lives are often conditioned around the possibility of violence. And acts of violence exert additional power over girls because the stigma of violence often attaches more to a girl than to her perpetrator. The experience of violence is devastating at the individual emotional and physical level. Its power to interrupt or fully disable girls' access to entitlements, social participation, andcrucially-safe and decent livelihoods is an equally compelling reason to stop it.

Violence is so pervasive in many societies that it has the feeling of being an active "plan" or even an opposing sector undermining the investments made by other sectors in girls' wellbeing. Part of the "plan" to deny the rights of girls, even when society has made progress, is to condition them to avoid opportunity in order to manage risk. As girls internalize their responsibility for managing this risk, they begin to precensor their potential.

\section{VIOLENCE IMPEDES GIRLS' ACCESS TO SERVICES}

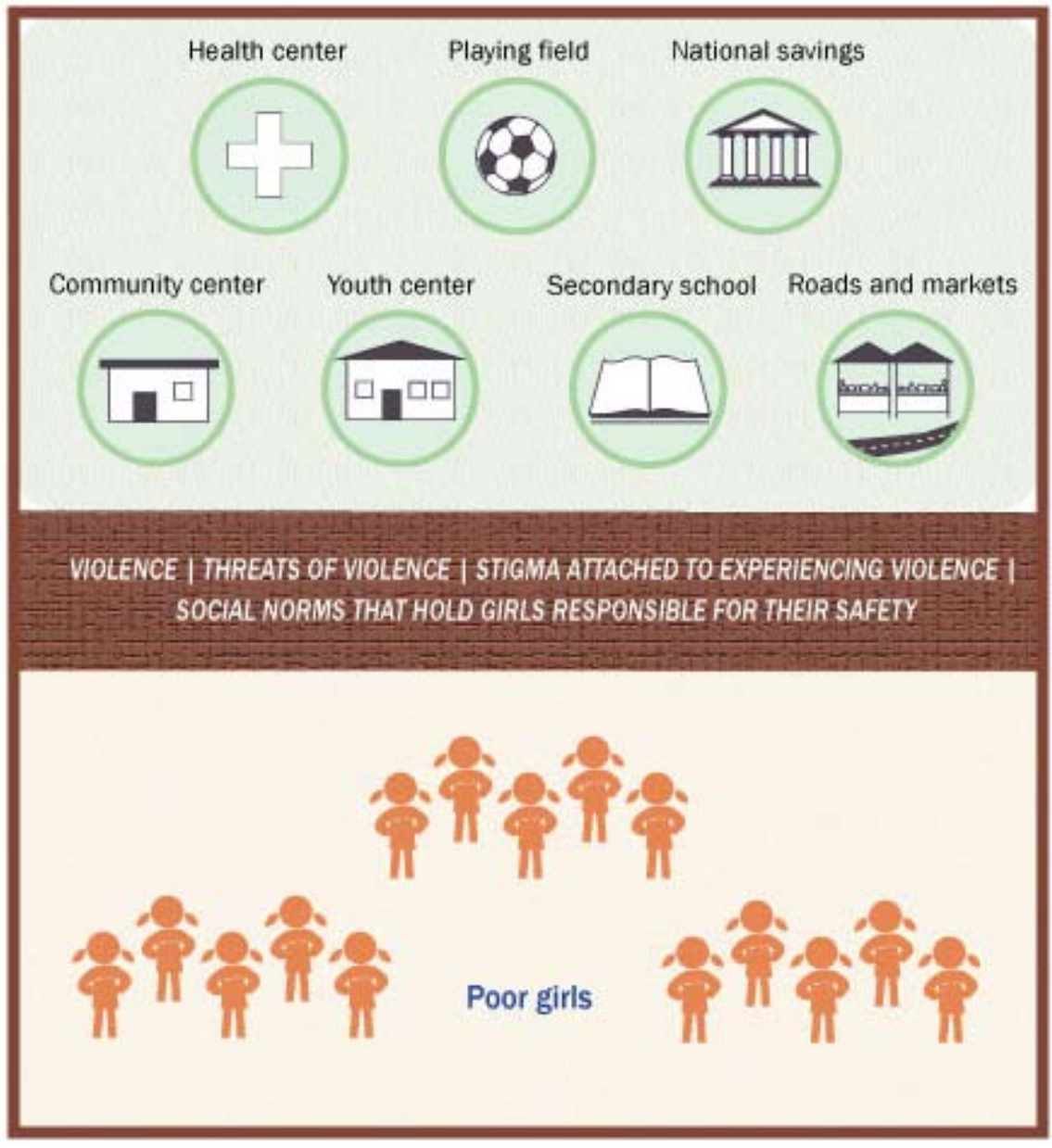

Extreme violence affects at minimum a third of all females and a high, possibly rising, proportion of girls younger than 15

Physical violence, including being beaten, raped, or otherwise mistreated is reported by a third of women worldwide. The perpetrators are usually family members or partners (Ellesberg and Heise). ${ }^{1}$ Accepting the challenges of collecting such sensitive data, including underreporting, it is noted that a high proportion of reported sexual assaults, often a majority, are experienced by girls younger than 19 years. In some places as many as half of reported sexual assaults are perpetrated on girls younger than 15. (See Table 1.)

The proportion of affected girls who report sexual violence is very low; in some settings, only about half of girls who experience sexual violence tell someone about the abuse. (Boys are also reluctant to report sexual violence.) The process through which girls must report violence can retraumatize them. ${ }^{2}$ In some settings, access to services is a barrier in and of itself, as many communities have few or no services for survivors of violence. Authorities and service providers rarely have training on how to treat cases of violence and even fewer people are trained on how to treat girl survivors of violence. Being treated with doubt and blame by service providers can cause immense psychological damage to adolescent girls and delay or impede the healing process.

Recent surveys conducted by the governments of Swaziland and Tanzania, with support from the US Centers for Disease Control and Prevention (CDC) and UNICEF, are documenting systematic levels of violence against 


\section{TABLE 1 A HIGH PROPORTION OF SEXUAL} ASSAULTS AMONG GIRLS

\section{PLACE}

Copperbelt, Zambia

Limpopo, South Africa

Malawi

Liberia

\section{AGE PROFILE OF FEMALE SEXUAL- ASSAULT SURVIVORS}

$49 \%$ are younger than $14,85 \%$ are younger than 19

$56 \%$ of people presenting at trauma centers were minor girls and $31 \%$ were preteen girls ${ }^{*}$

A national study showed that $50 \%$ of child sexual-assault cases were among children $2-13$ years of age*

Half of all reported rapes are experienced by girls younger than $15^{* *}$
*Keesbury, Jill and lan Askew. 2010. "Comprehensive responses to gender-based violence in low-resource settings: Lessons learned from implementation." New York, NY: Population Council. * *Personal communications, Ministry of Youth and Adolescent Girls Working Group meeting, Liberia, June 2008. children. The surveys found extremely high levels of violence. About a third of girls in both countries reported being abused before they reached 18 . The Swaziland report noted that about 40\% of girls who experienced violence were likely to experience it again (Reza). ${ }^{3}$ Further, the perpetrators of violence were those who tended to be close to girls (mainly males who lived in the same households and neighborhoods; a smaller percentage were teachers or religious authorities). The most frequent venue of violence was the girls' home. Stranger violence represented less than $15 \%$ of all violence in Swaziland and $32 \%$ in Tanzania. ${ }^{4}$

Child marriage, one of the most grievous forms of violence-and usually excluded in statistics of rape and abuse-continues at shocking levels in some communities. (See Figure 1.) If present trends continue, more than

\section{FIGURE 1 CHILD MARRIAGE AMONG FEMALES AGED 18-24 IN SUB-NATIONAL HOTSPOTS}

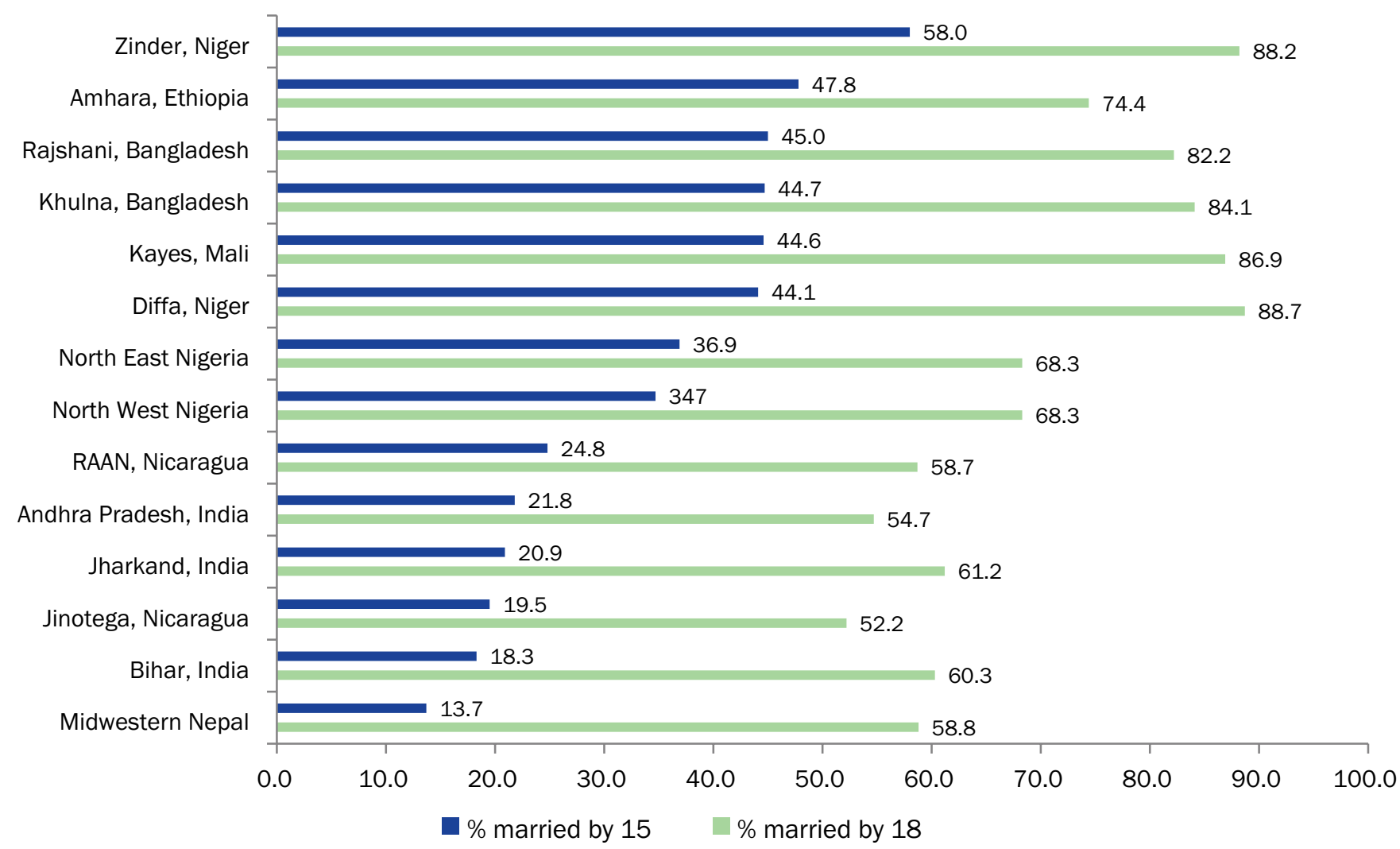

Source: Data compiled by Adam Weiner, Population Council, August 2011. Source: Population Council. 2009. The Adolescent Experience In-depth: Using Data to Identify and Reach the Most Vulnerable Young People. Country Reports. New York: Population Council. <http://www.popcouncil.org/ publications/serialsbriefs/AdolExplnDepth.asp>. 
100 million girls in the developing world will be subjected to this brutal rupture of their lives. Child marriage transits them forcibly into sexual slavery, which carries with it an elevated risk of poor outcomes, such as reproductive tract infections and HIV acquisition. Girls who are in and out of such marriages by the age of 20 (and child marriages are associated with marital disruption) have a particularly high risk of acquiring HIV. ${ }^{5}$

As young females seek more autonomy in sexual-marital decisions, in some settings arising in the context of a "modern dating culture" (Jejeebhoy), ${ }^{6}$ they may be subject to forced or tricked sex and may lack the negotiation skills and sheer physical power to protect themselves. The Demographic and
Health Surveys ask (in many, but not all countries) if the first sexual experience was forced or tricked. The prevalence of nonconsensual sex is often overlooked when conventional sexual education programs are designed.

\section{Girls who have experienced forced first-sex and report large age differences with partners}

The large age gap between girls and their partners or husbands often puts these girls at a disadvantage in avoiding violence and in negotiating healthy sexual behavior. The age difference between partners-whether married or not-has implications for the woman's ability to negotiate voluntary, safe, and protected sexual relations. Research shows that marriages between young women and older men are less equitable. (See Table 2.)

Acceptance of violence shrinks girls' sense of self, the hours of the day, and their lives

The role that violence plays in shaping girls' lives on a daily, weekly, and seasonal basis is quantifiable. Girls grow up within norms of constrained mobility defined by violence. The "decent" girl is submissive; failure to submit is met with force, which she may come to believe is justified. This cultural submission has deep roots in family traditions, asymmetrical spousal relations, and community norms, and is often sup-

\section{TABLE 2 PARTNER AGE DIFFERENCE AND GIRLS' VULNERABILITY}

\begin{tabular}{|c|c|c|c|c|c|c|c|}
\hline \multirow[b]{2}{*}{ COUNTRY } & \multirow[b]{2}{*}{ DHS YEAR } & \multicolumn{2}{|c|}{$\begin{array}{c}\% \text { OF FEMALES } \\
\text { AGED 15-24 WHOSE } \\
\text { FIRST SEX WAS FORCED }\end{array}$} & \multicolumn{2}{|c|}{$\begin{array}{c}\% \text { OF FEMALES AGED } \\
\text { 15-24 WHOSE AGE } \\
\text { DIFFERENCE WITH HER } \\
\text { FIRST SEXUAL PARTNER } \\
\text { WAS } 10 \text { YEARS OR MORE }\end{array}$} & \multicolumn{2}{|c|}{$\begin{array}{c}\text { \% OF FEMALES AGED 15-24 } \\
\text { WHOSE AGE DIFFERENCE } \\
\text { WITH HER CURRENT } \\
\text { SPOUSE/PARTNER IS } \\
\text { MORE THAN } 10 \text { YEARS }\end{array}$} \\
\hline & & NATIONAL & НОTSPOT & NATIONAL & НОTSPOT & NATIONAL & HOTSPOT \\
\hline Benin & 2006 & 27.2 & $\begin{array}{c}47.6 \\
\text { (Ouémé) }\end{array}$ & 18.9 & $\begin{array}{c}32.0 \\
\text { (Atacora) }\end{array}$ & 30.2 & $\begin{array}{c}43.5 \\
\text { (Donga) }\end{array}$ \\
\hline DRC & 2007 & 63.8 & $\begin{array}{c}84.4 \\
\text { (Maniema) }\end{array}$ & 14.9 & $\begin{array}{c}25.3 \\
\text { (Kasai Oriental) }\end{array}$ & 26.2 & $\begin{array}{c}35.6 \\
\text { (Kasai Oriental) }\end{array}$ \\
\hline India & 2005-06 & N/A & $\mathrm{N} / \mathrm{A}$ & 14.8 & $\begin{array}{c}42.4 \\
\text { (Assam) }\end{array}$ & 13.6 & $\begin{array}{c}34.6 \\
\text { (Assam) }\end{array}$ \\
\hline Liberia & 2007 & 9.5 & $\begin{array}{c}13.3 \\
\text { (South Eastern A) }\end{array}$ & 38.4 & $\begin{array}{c}53.8 \\
\text { (South Eastern A) }\end{array}$ & 30.3 & $\begin{array}{c}35.6 \\
\text { (South Eastern A) }\end{array}$ \\
\hline Mali & 2006 & 24.9 & $\begin{array}{c}33.4 \\
\text { (Sikasso) }\end{array}$ & 45.5 & $\begin{array}{c}65.0 \\
\text { (Timbuktu) }\end{array}$ & 53.4 & $\begin{array}{c}73.0 \\
\text { (Timbuktu) }\end{array}$ \\
\hline Nepal & 2006 & N/A & $\mathrm{N} / \mathrm{A}$ & 3.0 & $\begin{array}{c}5.4 \\
\text { (Western) }\end{array}$ & 8.1 & $\begin{array}{c}11.7 \\
\text { (Western) }\end{array}$ \\
\hline Rwanda & 2005 & $\mathrm{~N} / \mathrm{A}$ & $\mathrm{N} / \mathrm{A}$ & 27.0 & $\mathrm{~N} / \mathrm{A}$ & 17.3 & $\begin{array}{c}30.9 \\
\text { (Ville de Kigali) }\end{array}$ \\
\hline Uganda & 2006 & 25.2 & $\begin{array}{c}35.2 \\
\text { (Southwest) }\end{array}$ & 17.5 & $\begin{array}{c}28.6 \\
\text { (Western) }\end{array}$ & 20.1 & $\begin{array}{c}27.9 \\
\text { (East Central) }\end{array}$ \\
\hline Zambia & 2007 & $\mathrm{~N} / \mathrm{A}$ & $\mathrm{N} / \mathrm{A}$ & 7.8 & $\begin{array}{c}14.2 \\
\text { (Northern) }\end{array}$ & 15.5 & $\begin{array}{c}17.3 \\
\text { (Copperbelt) }\end{array}$ \\
\hline
\end{tabular}

Source: Data compiled by Adam Weiner, Population Council, August 2011. Source: Population Council. 2009. The Adolescent Experience In-depth: Using Data to Identify and Reach the Most Vulnerable Young People. Country Reports. New York: Population Council. <http://www.popcouncil.org/ publications/serialsbriefs/AdolExplnDepth.asp>. 
ported directly and indirectly by local and even national policies or interpretations of major religious tenets.

Girls with a weak sense of identity in empirically violent circumstances become conditioned to accepting and defending the use of force against them. ${ }^{7}$ Looking across the data from the Demographic and Health Surveys, a high proportion of girls justify violence against them for one or more reasons.
A shocking proportion of girls will justify violence against them in all circumstances. (See Table 3.)

Justification and experience of violence While men and boys may face some level of violence (in Tanzania 30 percent of girls, compared to about 14 percent of boys, experience sexual violence before age 18$)^{8}$ and may change daily patterns in small ways to improve their security, many girls can define few moments in which they feel completely safe and can identify virtually no spaces that they can inhabit with confidence. Systematic inquiries (Hallman, Erulkar, Amin) ${ }^{9}$ turn up very different sets of places where young males and females can move with both security and social acceptance. (See Tables 4 and 5.)

The same 24 hours that young males and females share have a very

\section{TABLE 3 JUSTIFICATION AND EXPERIENCE OF VIOLENCE}

\begin{tabular}{|c|c|c|c|c|c|c|}
\hline \multirow{2}{*}{$\begin{array}{l}\text { REGION/ } \\
\text { COUNTRY }\end{array}$} & \multirow{2}{*}{$\begin{array}{l}\text { DHS } \\
\text { YEAR }\end{array}$} & \multicolumn{2}{|c|}{$\begin{array}{l}\% \text { OF FEMALES AGED 15-24 } \\
\text { WHO THINK WIFE BEATING } \\
\text { IS JUSTIFIED UNDER } \\
\text { CERTAIN CIRCUMSTANCES }\end{array}$} & \multicolumn{3}{|c|}{$\begin{array}{c}\text { \% OF FEMALES AGED 15-24 } \\
\text { WHO HAVE EXPERIENCED } \\
\text { PHYSICAL VIOLENCE SINCE AGE } 15\end{array}$} \\
\hline & & NATIONAL & HOTSPOT & NATIONAL & HOTSPOT & $\begin{array}{c}\text { HOTSPOT } \\
\text { (EVER-MARRIED) }\end{array}$ \\
\hline \multicolumn{7}{|c|}{ SUB-SAHARAN AFRICA } \\
\hline Benin & 2006 & 44.6 & $\begin{array}{c}74.2 \\
\text { (Atacora) }\end{array}$ & $\mathrm{N} / \mathrm{A}$ & $\mathrm{N} / \mathrm{A}$ & $\mathrm{N} / \mathrm{A}$ \\
\hline DRC & 2007 & 82.6 & $\begin{array}{c}89.3 \\
\text { (Equateur) }\end{array}$ & 59.7 & $\begin{array}{c}75.4 \\
\text { (Equateur) }\end{array}$ & $\begin{array}{c}88.4 \\
\text { (Kinshasa) }\end{array}$ \\
\hline Liberia & 2007 & 60.6 & $\begin{array}{c}74.4 \\
\text { (North Central) }\end{array}$ & 32.5 & $\begin{array}{c}40.5 \\
\text { (Monrovia) }\end{array}$ & $\begin{array}{c}48.1 \\
\text { (Monrovia) }\end{array}$ \\
\hline Mail & 2006 & 77.3 & $\begin{array}{c}88.9 \\
\text { (Kayes) }\end{array}$ & $\mathrm{N} / \mathrm{A}$ & $\mathrm{N} / \mathrm{A}$ & $\mathrm{N} / \mathrm{A}$ \\
\hline Rwanda & 2005 & 50.6 & $\begin{array}{c}71.9 \\
\text { (Cyangugu) }\end{array}$ & 22.9 & $\begin{array}{c}35.7 \\
\text { (Umutara) }\end{array}$ & $\begin{array}{c}48.7 \\
\text { (Ville de Kigali) }\end{array}$ \\
\hline Uganda & 2006 & 72.4 & $\begin{array}{c}87.7 \\
\text { (West Nile) }\end{array}$ & 55.4 & $\begin{array}{c}71.3 \\
\text { (Eastern) }\end{array}$ & $\begin{array}{c}73.5 \\
\text { (Eastern) }\end{array}$ \\
\hline Zambia & 2007 & 63.1 & $\begin{array}{c}83.5 \\
\text { (Luapula) }\end{array}$ & 40.6 & $\mathrm{~N} / \mathrm{A}$ & $\begin{array}{c}59.5 \\
\text { (Copper Belt) }\end{array}$ \\
\hline \multicolumn{7}{|l|}{ ASIA } \\
\hline Bangladesh* & 2007 & 31.4 & $\begin{array}{c}47.5 \\
\text { (Barisal) }\end{array}$ & 26.7 & $\mathrm{~N} / \mathrm{A}$ & $\begin{array}{c}36.7 \\
\text { (Rajshahi) }\end{array}$ \\
\hline Cambodia & 2005 & 55.6 & $\begin{array}{c}84.9 \\
\text { (Svay Rieng) }\end{array}$ & 10.1 & $\begin{array}{c}24.3 \\
\text { (Pursat) }\end{array}$ & $\mathrm{N} / \mathrm{A}$ \\
\hline India & $2005-06$ & 47.3 & $\begin{array}{c}83.2 \\
\text { (Manipur) }\end{array}$ & 14.7 & $\begin{array}{c}28.8 \\
\text { (Tripura) }\end{array}$ & $\begin{array}{c}41.1 \\
\text { (West Bengal) }\end{array}$ \\
\hline Indonesia* & $2002-03$ & 29.6 & $\begin{array}{c}55.5 \\
\text { (W. Nusa Tenggara) }\end{array}$ & $\mathrm{N} / \mathrm{A}$ & $\mathrm{N} / \mathrm{A}$ & $\mathrm{N} / \mathrm{A}$ \\
\hline Nepal & 2006 & 23.6 & $\begin{array}{c}30.6 \\
\text { (Midwestern) }\end{array}$ & N/A & $\mathrm{N} / \mathrm{A}$ & $\mathrm{N} / \mathrm{A}$ \\
\hline Philippines & 2003 & 24.8 & $\begin{array}{c}66.1 \\
\text { (ARMM) }\end{array}$ & $\mathrm{N} / \mathrm{A}$ & $\mathrm{N} / \mathrm{A}$ & N/A \\
\hline
\end{tabular}


TABLE 4 GIRLS' RELATIVE ACCESS TO SOCIAL SAFETY NETS AND COMFORT IN THE COMMUNITIES (KEBELES) AROUND THE BUS STATION IN ADDIS ABABA

\section{INDICATORS OF VULNERABILITY AND SENSE OF WELL-BEING, BY SEX AND WORKING STATUS}

\begin{tabular}{|c|c|c|c|c|c|}
\hline \multirow[b]{2}{*}{$\begin{array}{l}\text { VULNERABILITY } \\
\text { CATEGORY }\end{array}$} & \multicolumn{2}{|c|}{ MALES } & \multicolumn{3}{|c|}{ FEMALES } \\
\hline & $\begin{array}{l}\text { NOT WORKING } \\
\qquad(\mathrm{N}=285)\end{array}$ & $\begin{array}{l}\text { WORKING } \\
(N=111)\end{array}$ & $\begin{array}{l}\text { NOT WORKING } \\
\quad(N=545)\end{array}$ & $\begin{array}{l}\text { WORKING NON- } \\
\text { DOMESTIC } \\
(\mathrm{N}=30)\end{array}$ & $\begin{array}{c}\text { DOMESTIC } \\
\text { WORKERS } \\
(\mathrm{N}=99)\end{array}$ \\
\hline Never been to school & 0.7 & 4.5 & 4.3 & 13.3 & $37.8 * * *$ \\
\hline Not living with parents & 26.0 & 41.4 & 45.9 & 66.7 & $97.0 * * *$ \\
\hline Migrated into Addis & 18.9 & 35.1 & 35.1 & 46.7 & $97.0 * * *$ \\
\hline Have many friends & 62.4 & 51.4 & 26.9 & 23.2 & $7.1 * * *$ \\
\hline $\begin{array}{l}\text { Feel scared of being beaten } \\
\text { by someone in neighborhood }\end{array}$ & 13.9 & 20.7 & 30.3 & 26.7 & $39.4 * * *$ \\
\hline
\end{tabular}

\section{TABLE 5 COMMUNITY SUPPORT, PERCEPTIONS OF SAFETY, AND EXPERIENCE OF CRIME, BY SEX}

\begin{tabular}{|c|c|c|}
\hline STATEMENT & $\begin{array}{c}\text { BOYS } \\
(\mathrm{N}=400)\end{array}$ & $\begin{array}{c}\text { GIRLS } \\
(\mathrm{N}=676)\end{array}$ \\
\hline \multicolumn{3}{|l|}{ Experience of social support in the neighborhood } \\
\hline You have many friends in the neighborhood & $59.0 * * *$ & 23.8 \\
\hline $\begin{array}{l}\text { If you didn't have a place to sleep, someone in } \\
\text { your neighborhood would take you in }\end{array}$ & $33.3 * * *$ & 18.9 \\
\hline $\begin{array}{l}\text { If you needed money urgently, there is someone } \\
\text { in your neighborhood who you could borrow from }\end{array}$ & $22.0 *$ & 16.0 \\
\hline $\begin{array}{l}\text { You have a place in the neighborhood (other than } \\
\text { home or school) to meet your same-sex friends }\end{array}$ & $47.5 * * *$ & 13.0 \\
\hline
\end{tabular}

Differences between groups significant at $*<0.05 ; * * p<0.01 ; * * * p<0.001$.

Source: Erulkar, Annabel. "Adolescent life in low income and slum areas in Addis Ababa,

Ethiopia." 2004. Population Council.

different feel, with girls in some settings unable to identify even an hour in which they feel safe. ${ }^{10}$ Girls' safety, both absolutely and relative to males, in the household, community, and school, and the amount of fear of harassment experienced, can be quantified (Hallman, Erulkar, Amin). ${ }^{11}$ Safety scans (Bruce, Austrian), ${ }^{12}$ offered in workshop settings or as part of formally conducted surveys, can reveal perceptions of safety among girls in different social categories (and may provide systematic comparisons with males as well).

A study of strategies that girls in Zambia use to protect themselves from HIV was telling. ${ }^{13}$ Perhaps the most striking findings were not the high levels of violence (more than one-third of the girls knew a girl who had been abused by a teacher and almost half knew a girl who had been abused by an intimate male in the household) but the fact that 86 percent noted that their response to such violence had been incorporated into their daily plans and their response was to "stay home." Girls' withdrawal from opportunities, playing it safe by limiting options, and crossing out whole parts of the environment (markets, industries, jobs, social entitlements at health clinics) all arise because of fears about safety.

Human rights frameworks are often applied in a manner geared toward the realities of dominant, particularly male, populations

Official attempts to protect girls and women from violence-such as human rights' frameworks and violence-reduction policies and procedures-often overlook the protective and supportive infrastructures that males have but females lack. Girls and women, to a much lesser extent than males, cannot freely and regularly gather with one another, because their movements are controlled by others. The venues in which females are most likely to experience violence are intimate spaces and places with nominal protection. The most likely perpetrators or complicit adults are duty-bearers (such as males who are residents of the household/neighborhood, those who would be romantic partners, parents, teachers, employers, legal authorities, and sometimes religious figures). 
Summing up: The consequences at the individual and social level of violence are so grave that prevention is the first priority

The individual experience of violence carries well-documented devastating and long-term-both over the life course and intergenerational-physical, psychological, sexual, and economic results.

Studying violence at the individual level may be usefully conceptualized as an attack on a core "stock"-human capital and dignity-from which there may be no real "recovery." While many females bravely reclaim a valued life, a substantial population will not achieve a full return to confident agency and bodily integrity. Long after the treatment or repair of the body, survivors of violence may have difficulty regaining a sense of control over their lives. Female survivors of violence exhibit long-term health effects, including chronic-pain syndromes, drug and alcohol abuse, unwanted pregnancies, pregnancy complications, sexually transmitted infections (including HIV), increased rates of morbidity and mortality, mental health problems, gynecological problems, and decreased functioning (Campbell). ${ }^{14}$ Social and economic effects are reflected in increased absenteeism, decreased labor force participation, and reduced productivity. These outcomes lower girls' ability to earn in ways commensurate with their skills and to take physical control of earnings. A recent review in Swaziland, impressive in the depth and breadth of its inquiry, concluded that the short-term and long-term effects were so devastating that the priority must simply be prevention (Reza). ${ }^{15}$

\section{THE CURRENT LANDSCAPE}

Programs prioritize treatment and perpetrators over prevention and girls

It is consistent with the human rightsbased approach to prioritize the engagement of the most directly affected individuals. Many gender-based violence-prevention programs, including those that note the young age at which many violations take place, have more planned engagement with authority figures and perpetrators than with girls themselves. They are working "on behalf of girls" but not with girls. These initia- tives, seen in isolation, seem worthy enough, but when put in context, they may be substantially over-resourced relative to practical and strategic needs. Recently, a large sub-Saharan country enacted an ambitious program to prevent gender-based violence and noted that a very high proportion of violence was among adolescent girls and young women. Yet the plan proposed spending less than $5 \%$ of total resources on direct engagement with young populations, mixing boys and girls in beneficiary groups, and it did not have distinct performance benchmarks for males and females. Table 6 gives some sense of the current allocation of resources and which groups are primarily engaged.

Youth programs fail to reach girls often or at all in proportion to their need Many child health, civic participation, social development programs, and most especially youth programs have been mounted in the name of addressing young peoples' vulnerability in late childhood and early adolescence, and providing a safety net and pathway into civic participation. Strikingly, those segments of the child and adolescent population at highest risk and with the least social assets are the least likely to be beneficiaries of conventionally configured programs and policies. (See quote below.)

For example, because youth and other safety net programs rely upon demand rather than on purposeful recruitment, there is "elite capture" not simply of adult males, but also of some females. Girls in domestic service in Addis Ababa have almost no access to "youth services." A youth program in Monrovia, Liberia, served almost 12 times more girls aged 15-19 who were

There is a persistent failure to invest in girls' protective assets. Imagine a Civil Rights Movement that failed to register African Americans to vote. Can one imagine an effective effort to raise wages that simply made appeals to executives and never mobilized the workers? in school than girls aged 10-14 who were out of school. ${ }^{16}$ (See Table 7.)

Promising research is beginning to define factors that protect girls from violence and make them more able to clearly see and manage their environment

Hallman found that girls' friendship networks were much less developed than boys' (typically, in South Africa the poorest boys had more friends and regular access to them than the richest girls) and crucially that greater social isolation was strongly correlated with experiencing forced sex. ${ }^{17,} 18$ (See Figure 2.)

Cross-sectional data (Lloyd) ${ }^{19}$ for many countries suggest that girls who are in school during adolescence (especially those at grade for age) are less likely to be sexually active and to experience sexual coercion, reproductive tract infections, unwanted pregnancies, or HIV. A recent survey in Swaziland demonstrated that the risk of childhood sexual violence is greatest among those who were not attending school at the time of the study, suggesting that greater educational opportunities could help prevent sexual violence (Breiding et al.). ${ }^{20}$ Findings from several studies suggest that the risk of childhood sexual violence is higher among girls whose relationship with their biological mothers had not been close, suggesting that a strong mother-daughter relationship may protect a girl from experiencing sexual violence. (Breiding et al.). ${ }^{21}$ Being in a two-parent household is similarly protective. Being an orphan, on the other hand, puts a girl at significantly higher risk for experiencing violence. Having specific knowledge of your community as opposed to general knowledge of services is protective. Health and social and economic assets are closely linked. Girls who had a financial goal, in a South Africa study, were more likely to realistically assess HIV risk and more likely to have an HIV test. ${ }^{22}$

Whereas programs cannot restore families, they can create social support, specific knowledge, and new skills. Even the most disadvantaged girls (girls in domestic service long detached from their families) can build their social capital and protective assets in ways that increase their prospects of both a safer and a more decent life. 


\section{TABLE 6 RESOURCES AVAILABLE}

\begin{tabular}{|c|c|c|c|c|}
\hline $\begin{array}{l}\text { PROGRAM SUBJECT } \\
\text { CATEGORIES }\end{array}$ & $\begin{array}{c}\text { PREVENTION } \\
\text { AND BUILDING } \\
\text { PROTECTIVE ASSETS }\end{array}$ & MITIGATION & $\begin{array}{l}\text { TREATMENT: ACCESS } \\
\text { TO AND EFFECTIVE } \\
\text { PROVISION }\end{array}$ & $\begin{array}{l}\text { REINTEGRATION } \\
\text { AND RECOVERY }\end{array}$ \\
\hline $\begin{array}{l}\text { Girls at risk } \\
\text { (girls in domestic } \\
\text { service, oldest girls/ } \\
\text { primary school, young- } \\
\text { est girls/secondary } \\
\text { school, out-of school } \\
\text { girls aged 10-14 }\end{array}$ & $\begin{array}{l}\text { Negligible } \\
\text { resources }\end{array}$ & $\begin{array}{l}\text { Negligible } \\
\text { resources }\end{array}$ & $\begin{array}{l}\text { Some } \\
\text { resources }\end{array}$ & $\begin{array}{l}\text { Negligible } \\
\text { resources }\end{array}$ \\
\hline Police & N/A & N/A & More resources & N/A \\
\hline Lawyers & $\mathrm{N} / \mathrm{A}$ & N/A & More resources & $\mathrm{N} / \mathrm{A}$ \\
\hline Judges & N/A & $\mathrm{N} / \mathrm{A}$ & More resources & $\mathrm{N} / \mathrm{A}$ \\
\hline Health workers & N/A & $\mathrm{N} / \mathrm{A}$ & More resources & N/A \\
\hline Teachers & N/A & N/A & More resources & N/A \\
\hline $\begin{array}{l}\text { Males as potential } \\
\text { abusers or allies (e.g., } \\
\text { intimates, brothers, } \\
\text { fathers, partners, } \\
\text { unrelated males) }\end{array}$ & $\begin{array}{l}\text { Some } \\
\text { resources }\end{array}$ & N/A & $\mathrm{N} / \mathrm{A}$ & N/A \\
\hline
\end{tabular}

Source: Bruce, Judith. Interagency Youth Working Group Presentation, 3 June 2010.

\section{TABLE 7 OLDER GIRLS IN SECONDARY SCHOOL WERE ALMOST NINE TIMES MORE LIKELY TO PARTICIPATE IN A COMMUNITY-BASED PROGRAM THAN YOUNGER OUT-OF-SCHOOL GIRLS}

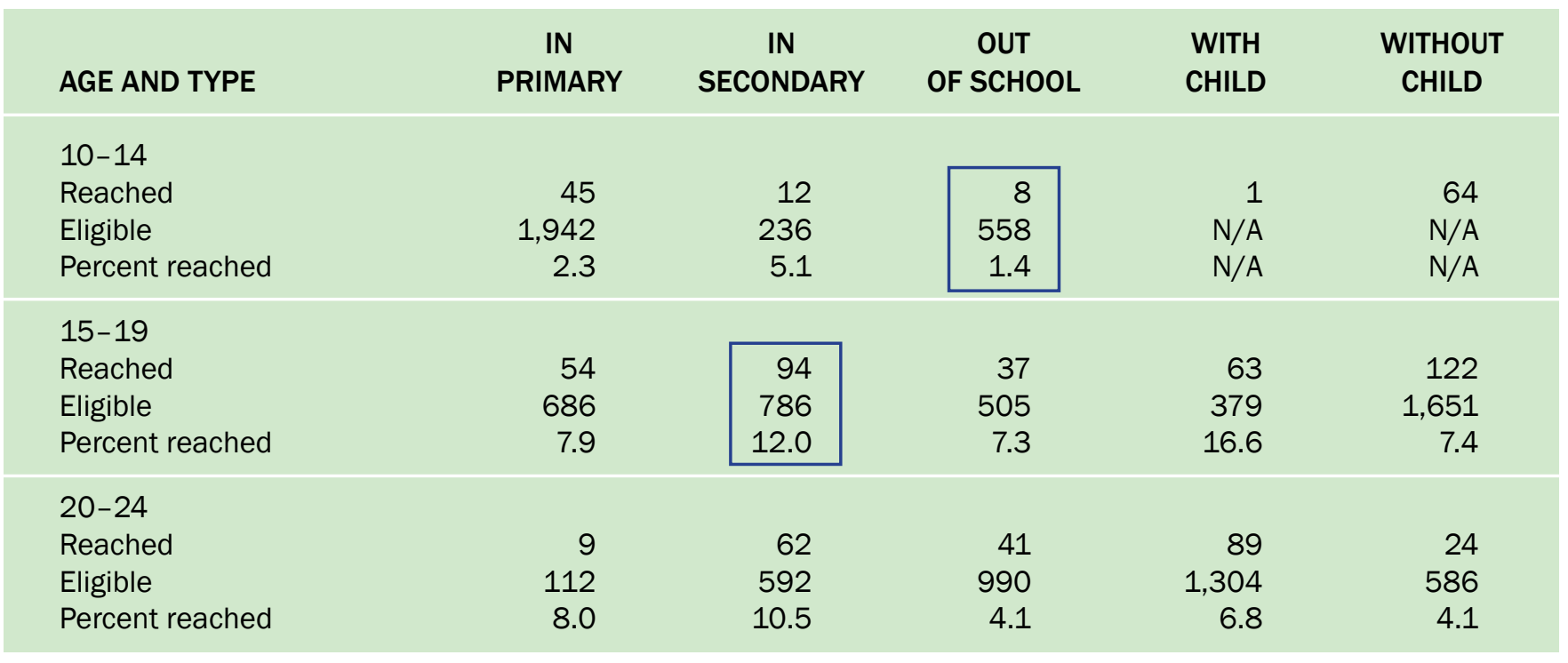

Source: Tabulations by Adam Weiner. 2007 Liberia DHS and 2008-2009 Liberia Coverage Exercise with pilot coverage exercise data from four community-based programs. 


\section{AN INVERSION OF CARE}

Those at lesser risk, with greater social assets (stable homes, schooling) are receiving the majority share of youth-serving resources

- In school (older) boys

- Unmarried males

- Urban born, living in two-parent household

- Older adolescents, youth 20+, even 24+

Those at greatest risk, with least social assets (migrant, less stable families, lesser or no schooling, experiencing the most frequent unprotected sexual relations) are receiving a negligible share of youth-serving resources

- Out of school (younger) girls

- Married girls

- Migrant, rural origin, living apart from parents

- Youngest adolescents, 10-14

Source: Bruce, Judith. November 2006. "Using data to count, advocate for, and invest in adolescent girls: An Ethiopian case study. Additional Source: Mekbib, T., A. Erulkar, and F. Belete. 2005. "Who are the targets of youth programs: Results of a capacity building exercise in Ethiopia," Ethiopian Journal of Health Development 19(1): 60-62.

\section{PROMOTED POLICIES AND PRACTICES}

Use data to find girls at exceptionally high risk

Data exist to identify specific places where there are high concentrations of females at high risk for experiencing violence (e.g., the Multiple Indicator Cluster Survey (MICS), Demographic and Health Surveys (DHS), and the National Centers for Disease Control and Prevention (CDC) Surveys completed for Swaziland, Tanzania, Zimbabwe, and planned for Haiti). Culturally prescribed violence such as child marriage or female genital mutilation (FGM) is often concentrated in specific geographic locations or ethnic/ religious communities. There is often subnational variation in the proportion of young women who accept violence. For example, in Benin, ${ }^{23}$ though the national average of girls who think wife beating is justified under certain circumstances is almost $45 \%$, there are also hotspots where as many as $74 \%$ of girls think wife beating is justified. In Haiti (DHS 2006), ${ }^{24}$ almost double the proportion of girls in the north as in the south justify violence.

There are similar variations in the proportion of girls who have experi-

\section{FIGURE 2 THOSE WITH FEWER SOCIAL CONNECTIONS ARE MORE LIKELY TO EXPERIENCE FORCED SEX (EVER-BEEN-PHYSICALLY-FORCED 14-16-YEAR-OLD FEMALES)}

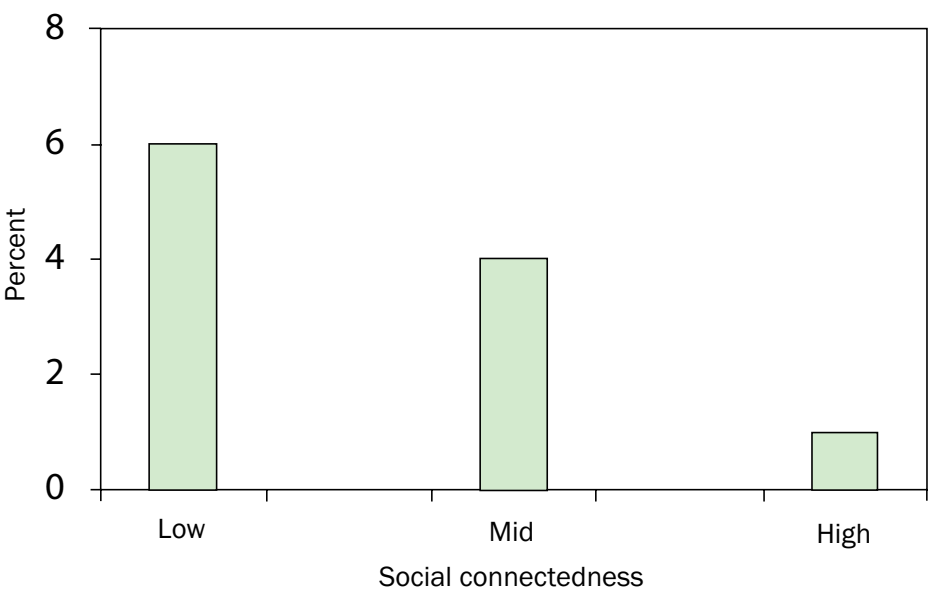

Sources: Hallman, K. 2004. "Socioeconomic disadvantage and unsafe sexual behaviors among young women and men in South Africa," Policy Research Division Working Paper No. 190. New York: Population Council. Bruce, Judith and Kelly Hallman. 2008. "Reaching the girls left behind," Gender \& Development 16(2): 227-245.

enced forced sexual relations and in other circumstances that starkly raise vulnerability, such as girls aged 10-14 who are out of school and living apart from parents or are in domestic service. ${ }^{25}$ In sum, there is enough data to establish in most locations a basic epidemiology of violence, and existing data can facilitate the identification in advance, of populations of females who are at elevated risk for suffering violence. (See Map, page 10.)

Devote more resources to building protective assets of the girls at most risk

Violence-reduction programs should engage the constituency at the basein this case, adolescent girls-offering them the right to information and opportunities for assembly and expression of their views. These rights of participation are not well understood or implemented and are the most challenging rights to secure, especially for marginalized and vulnerable populations. Imagine a Civil Rights Movement that failed to register African Americans to vote. Can one imagine an effective effort to raise wages that simply made appeals to executives and never mobilized the workers?

Job One is to develop the protective assets of the youngest females at highest risk of the most severe violence. If this value is served, the majority of resources would be allocated to building the protective assets of vulnerable populations and, concurrently, appropriate but lesser resources could be allocated to second-tier clients, for example, building the professional skills of established authority figures or addressing potential perpetrator populations.

\section{Use girls' knowledge to design prevention, mitigation, reporting procedures, and treatment programs}

Few current programs are incorporating girls' perspectives, even as survivors of violence, in program design and implementation. The vast majority of resources build the social capital and knowledge of people who have authority over girls, such as teachers 
PERCENT OF GIRLS 10-14 NOT IN SCHOOL AND NOT LIVING WITH EITHER PARENT IN MOZAMBIQUE $(137,768)$

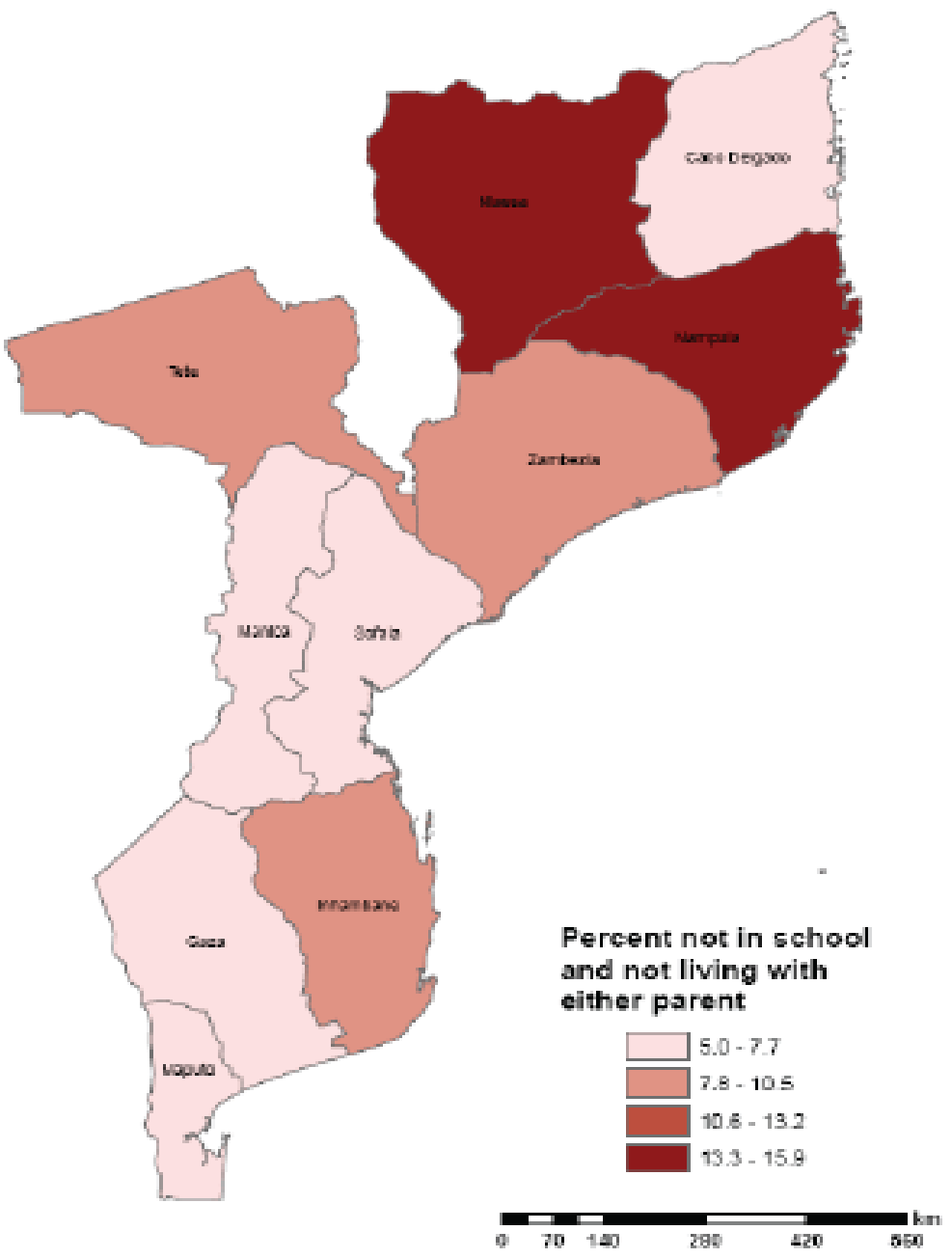

Source: “The Adolescent Experience In-Depth: Using Data to Identify and Reach the Most Vulnerable Young People: Mozambique 2006." New York: Population Council, 2009. <http://www. popcouncil.org/publications/serialsbriefs/AdolExpInDepth.asp>. or those who are involved in bringing the perpetrators of violence to justice (police and judges). A recently designed national program to reduce violence in a sub-Saharan African country with extremely high levels of violence had evaluation measures at the level of male peers, but no measures for effecting change among the young females who were most likely to be victims of the violence. Youth programs, among the few initiatives that governments design to be preventative and offer safety nets, systematically neglect exactly
The Population Council and UNFPA Adolescent Data Guides (available for over 50 countries) can be accessed via www.popcouncil. org/girlsdata or www.unfpa.org/youth/dhs_adolescent_guides.html. those females who are at high risk of violence: 10-14-year-olds who are out of school, 10-14-year-olds living with one or no parent, and underage girls in exploitative work. ${ }^{26,27}$

The Population Council has developed a safety scan tool for use by girls and boys to define times of the day, week, season, or situation that are sources of threat. Girls themselves should be asked to identify when they feel at risk, according to:

- Days of the week

- Seasons

- Situations (like asking for a grade or walking to or from school)

- Hours of the day

- Economically lean times and better times

Girls can be asked to identify situations and special events that bring heightened risk. Examples of this include school vacations, times when men have money, festivals, or sporting events (World Cup). In South Africa, girls identified November and December as months when they felt they were more under pressure to exchange sex for gifts and money, because school fees were due then (Hallman). ${ }^{28}$

This exercise has been conducted in a number of settings, including Burkina Faso, Haiti, Tanzania, and Zambia. In Haiti, girls were very clear that there were no times during which members of any of three categories of vulnerable females (domestic workers, 10-14-year-old out-of-school girls, and heads of household) felt safe. The safety scan tool lays the foundation for a practical discussion of what a safety plan might look like. An excerpt of the $\operatorname{scan}^{29}$ focuses on the seasons that bring risk. (See Figure 3.)

Create regularly available platforms and spaces for girls, particularly those at the highest risk of exploitation

Girls, unlike boys, do not have regular, safe places to meet nonfamily friends (a loss in and of itself) outside of home or school. Disadvantaged girls are strangers in the household in which they live and do not attend school. 


\section{FIGURE 3 SAFETY SCAN TOOL}

\section{SEASONS THAT BRING RISK}

Harvesting

Rainy season

Migration for work

School fees are due

Holidays

When school is in session

(Other)

(Other)

(Other)
WHY THE SEASON BRINGS RISK

WHAT CAN BE DONE TO REDUCE RISK

Conceptualized by Judith Bruce and Karen Austrian. Published by Austrian, K. and D. Ghati. 2010. Girl Centered Program Design: A Toolkit to Develop, Strengthen and Expand Adolescent Girls Programs. Population Council

Other girls have left their community, often forcibly.

All human beings need friendship and social support. Social support and friendship not only reduce girls' susceptibility to violence but can also serve as platforms from which to increase knowledge about rights, develop specific safety plans, and provide safe spaces in which they can discuss the sensitive and threatening elements in their lives. A family of peers with a mentor is a vital asset in and of itself. It is also a means by which a girl can learn her rights, come to understand teacher codes of conduct, have access to services and support, and obtain justice when she needs it.

Creating regularly available venues will likely increase the level of reporting about violence; girls in this environment may have an increased sense of what constitutes violence, and accept it less. They may also feel more trusting in disclosing difficult situations they are facing. ${ }^{30}$

\section{Purposefully recruit at-risk girls}

As observed earlier, assuring the participation of the girls at the highest risk (measured by social exclusion, family living arrangements, work and school status, prevalence of cultural norms, and migration status, for example) will require their purposeful recruitment. Mapping the community of girls is essential and allows the identification of the most vulnerable, such as girls in domestic service. ${ }^{31}$
Anchor programs with girls as the core client: Reach out to others selectively and based on girls' assessments

Effective programs must navigate many gatekeepers and limiting structures so that girls remain the key, anchoring client. While others-religious authorities, teachers, parents, male peers, and older males-may be engaged, the girls must be assured their central place as the core clients. Consistent with any human rights agenda, the affected population, the girls themselves, must be the central participants in the program and majority beneficiaries. To the extent that

\section{Even the most disadvantaged girls can increase their prospects of both a safer and more decent life.}

other actors are engaged as allies, girls' perspectives should inform program directions and messages.

Determine which (if any) media could make a difference based on girls' experiences

There's often a rush to move to media with the notion that violence can be reduced with some sort of social marketing campaign. These campaigns are often undertaken with no investigation as to girls' relative access to media in the first place (radio, television) or the meaningfulness of the messages. This is often a simple way to spend money and appear to be advocating, but it is not clear that these campaigns build girls' protective assets. In general, for behavior change and certainly for vulnerable groups, specific access to information is far more effective than generalized messages. Girls, for instance, need to know specific risky scenarios. As an example of a risky scenario, girls in the Haitian workshop identified "sharp guys" who lure insecure, younger girls out on dates that often end in gang abuse. In Zambia, girls identified teachers who insist that girls come to their homes to receive a grade. This behavior should be covered in a teachers' code; girls are currently unaware of these codes because they are not posted or discussed with them. Perhaps the most well-known experiment was one in Kenya in which high school girls were informed that older partners were more likely to have HIV than younger partners. This led to a change in both attitudes and partner selection. ${ }^{32}$

\section{Protecting girls as they seek justice}

For survivors of violence, seeking justice can be difficult and can often re-traumatize adolescent girls. Girl survivors often face doubting authorities who do not know how to properly treat them; there have been reports of clinicians inserting a speculum in girls-even 
prepuberty-which is a forbidden and dangerous clinical process. Mistreatment by medical providers often means further medical complications and little access to necessary medical treatment including post-exposure prophylaxis for HIV and other sexually transmitted infections and emergency contraception to decrease risk of pregnancy. Because of their age, girls are required to be accompanied by a trusted guardian or ombudsman for many services. This can hinder justice because a high proportion of perpetrators are family members and other people who are close to families. Sometimes culpable or complicit adults must give consent for medical treatment for the initiation of legal processes. ${ }^{33}$ Furthermore, legal systems are complex and difficult to navigate, even for adults. Many countries lack laws to protect and promote the rights of women and girls.

The Adolescent Girls Legal Defense Fund has developed guidelines for better addressing violations of girls' rights and equipping legal systems to meet the needs of adolescent girls. Among their recommendations:

- Require gender-sensitivity training for all personnel (police, prosecutors, clinicians, and judges) who deal with adolescent girls' legal needs.

- Ensure that medical exams are quick, minimally invasive, and carry few reporting requirements.

- Take special measures for adolescent girls in trials, such as:

- Providing separate waiting rooms for survivors and witnesses to avoid contact with perpetrators.

- Being sensitive during crossexamination to counter harassment of survivors.

- Allowing the use of screens or in-camera testimony to avoid contact with perpetrators.

- Keeping girls informed about the legal process and its outcomes.

- Limiting the number of times a survivor must testify.

- Enforcing time limits within which legal proceedings must be initiated and concluded. ${ }^{34}$
Measuring results at the level of the girl

Judging from programmatic efforts thus far, there appears to be a deep resistance to center violence-reduction programs on building the assets of girls themselves, even as a first step. Indeed the failure to measure any change at the level of the girl is an indicator of how off-track we have been. There is a strong bias to measuring inputs (like radio messages and number of police trained) rather than girl-level change. While it is important to document the thoroughness of the implementation, the most salient results are the returns to the core client population.

A clear indication that a program is girl-centered is that it has girl-level measures. Existing research suggests that there are a number of types of social capital (friendship networks, affiliations to groups that meet regularly) and safety nets ${ }^{35}$ (someone to turn to in an emergency or a place to spend the night) that are protective.

There is a final, methodological reason to measure results at the level of the girl. As girls (and the general community) become sensitized, many things that were previously defined as acceptable may be redefined as unacceptable and reported as violent. Negative reports about quality of services increase when clients are informed about their rights or appropriate expectations about care. Similarly, we can expect that adolescent girls who are sensitized and supported may initially report more abuse. Programs cannot guarantee a girl's safety, but they can measure how well prepared she is to deal with violence, by assessing her protective assets, such as having someone to turn to in a crisis and having specific safety plans. Programs can most likely measure shifting levels of comfort with violence within the community, and they can document expanding areas and times of day in which girls feel safe. Many of the shortterm measures of protective assets should be achievable within relatively short periods of time. For example, girls can acquire personal documentation and a more explicit sense of risk in their environment, and can evolve specific plans and knowledge to avoid it.
RESOURCES: LEARNING LAB PROGRAMS, PUBLICATIONS, AND TOOLS

Multilevel effort to change child marriage norms and support married girls: Berhane Hewan, Ethiopia ${ }^{36}$

The Population Council's Berhane Hewan program in Ethiopia measured its success at the level of the girl. The program assessed levels of child marriage, girls' social isolation and attitudes, along with girls' comfort in different parts of the community and access to different degrees of social participation. The program specifically addressed the interrelated factors that made a girl liable to be married as a child-these included her exclusion from school, her lack of friendship networks, her lack of access to a mentor or any kind of safety net (someone to turn to in an emergency). At the same time, the program engaged gatekeepers and actively discussed child marriage. It incentivized communities to support a high proportion of girls going to school on a regular basis. For those girls above school age (often by early adolescence with a lack of schooling), girls clubs were established, and the girls who were already married (regardless of age) attended girls clubs once a week. The result of this program was to delay the age at marriage by two years, reducing the acceptance and practice of an extreme form of sexual violence, and to provide health and social support to married girls.

For more information, see http://www.guttmacher.org/pubs/ journals/3500609.pdf, or contact Dr. Annabel Erulkar at aerulkar@ popcouncil.org.

Girl spaces in school: Our girls, our future-building synergy to end violence against girls in Zambia

A program underway in Zambia purposefully builds girls' protective assets. Currently, in six schools, four different organizations are experimenting with the creation of girls' clubs with an emphasis on the oldest girls in primary school and the youngest girls in secondary school, in 


\section{GIRLS' SAFE SPACES CAN OFFER:}

- A safe, reliably available space apart from home and formal schooling in which to meet friends

- Friends: A dense network of nonfamily peers

- Mentors and role models to learn from, and who can intercede

- Experience being part of a team, cooperating and leading

- Literacy, health knowledge, social mobility: Foundations of autonomy

- Financial literacy and savings

- Documentation for health, work, citizenship

- A place to conduct and post safety scans

- Develop specific girls' self-protection plans and crisismanagement options

- Know teacher and other professional codes of conduct

- Referral and management of challenges and crises (harassment, threats of child marriage, FGM, pregnancy, rape, violence)

- Accessing entitlements, including HIV-related

- Planning for seasonal stresses, like school fees and food shortages, which often increase pressure to exchange sex for gifts or money

- Dealing with prolonged illness, death, inheritance, succession planning

- Participation, activity, fun

Bruce, Judith. "Reaching The Girls Left Behind: Targeting Adolescent Programming for Equity, Social Inclusion, Health, and Poverty Alleviation." April 2007. Prepared for "Financing Gender Equality: A Commonwealth Perspective," Commonwealth Women's Affairs Ministers' Meeting, Uganda, June 2007.

light of the fact that girls around the time of puberty appear to be the most vulnerable. The girls clubs meet once a week on school premises, led by pairs of teachers, mothers, or peer mentors, and work through a wide-ranging curriculum that covers health, social issues, and financial literacy. The clubs also deploy suggestion boxes where girls can leave messages, and teachers learn a code of conduct and post it so the girls (and everybody else) can see it. ${ }^{37} \mathrm{~A}$ girl should know, as a teacher should know, that it is unacceptable for a teacher to ask a student to visit his home to receive a grade or to engage with them personally in any way outside of the classroom. This program is innovative insofar as it has moved from a concern about rape and redress to prevention and engaged young males who were identified in parallel locations where they were working with girls to maximize synergistic benefits.

For further information, please contact Caroline Muthoni Muriithi at cmuriithi@equalitynow.org.

\section{Promoting safe workspaces for} women working in bars: Tanzania

The TAMASHA project, which is underway in Dar es Salaam and being rolled out in Arusha, addresses the vulnerability of young women (officially aged 18-24, but sometimes 16 and younger) working in bars. Bar workers receive salaries well below minimum wage and work in an environment in which bar owners, male co-workers, and patrons expect them to submit to sexual harassment (fondling, slapping, etc.), and if they fail to submit they are in danger of losing their jobs. Most bar owners are not committed to ensuring that these young women are covered by such workplace policies as health insurance, protection against abuse and harassment, legislation on the minimum wage, or even HIV workplace interventions. TAMASHA is creating a network to increase these young women's social support and could, under Tanzanian law, include a union of bar workers to protect their rights and negotiate appropriate working conditions and protection. The biweekly meetings of the girls/young women will give them a chance to explore their lives together in a supportive environment. Other stakeholders such as bar owners will be included in the conversations to develop and implement minimum standards of payment and treatment in this risky industry. They will individually and collectively fight for a safe environment, zero harassment, and acceptable working conditions.

For further information, please contact Richard Mabala, rmabala@ yahoo.com.

\section{Biruh Tesfa (Bright Future):}

Providing meeting spaces, skillbuilding, and protective assets for domestic workers, orphans, and migrants in urban Ethiopia

This project-a collaboration between the Population Council, the Addis Ababa Youth and Sport Commission, and the Ethiopia Ministry of Youth and Sporthas reached up to 20,000 girls across six cities in Ethiopia, recruiting the out-of school girl population at highest risk. Girls meet in existing community halls and facilities donated by local administrations. Meetings are held 3-5 times a week. Biruh Tesfa aims to address adolescent girls' social isolation by building their social capital and participation and giving them access to basic literacy, life skills, HIV and reproductive health education, and specific knowledge of resources in their catchment areas. All participating girls receive a project identification (ID) card with their photo. 


\section{BASIC DESCRIPTIVE MEASURES OF GIRLS' STATUS FRAMING OF SOCIAL CAPITAL AND POTENTIAL VIOLENCE RISK \\ - Age/documentation of age \\ - Living arrangements \\ - Schooling status \\ - Marriage status \\ - Childbearing status \\ - Migration status \\ - Paid and unpaid work \\ - Savings experience \\ - Density of friendship networks \\ - Regular access to a place to meet nonfamily peers \\ - Levels of social affiliation/group membership \\ - Reported comfort level in school and community \\ - Sexual activity status (if possible)-whether first sexual experience was tricked or forced}

A 2009 evaluation determined that girls' social networks and safety nets can be built. Girls in the program report increases in friendship networks in their neighborhoods and having places outside the home to meet other girls. Girls in the project site were significantly more likely to have undergone voluntary counseling and testing for HIV compared with girls in the control site. ${ }^{38}$

For further information, please contact Annabel Erulkar at aerulkar@ popcouncil.org.

\section{Abriendo Oportunidades: "Safescaping" with a rural girls' program in Guatemala}

The Population Council's Abriendo Oportunidades program, working with indigenous girls' clubs in the Mayan Highlands of rural Guatemala, has developed an approach called "safescaping," which is being piloted in 3 of 40 program vil- lages. Safescaping facilitates adolescent girl-centered strategies to prevent and address violence against girls. Young female leaders (aged 15-24), with mentor support, use GPS technology to map their communities. First, they define the community's boundaries (the first time some of these villages have ever been mapped), then they go house to house and identify girls who are eligible to participate in the program.

During the mapping exercise, girls (aged 12-15) designate what parts of the community, service points, and facilities they define as "safe," "somewhat safe," and "unsafe." They then present these maps to a cross-section of the community (some of the elders, those on the development committee, school teachers, older and younger males, and interested family members). This allows participants to see the world as girls see it, including its safety parameters. Often overlaid on the village maps are the common daily routes along which girls travel (for example, to school). Points of concern with regard to girls' safety (e.g., unmowed fields, places where men gather, truck stops) are marked. In some instances, girls have noted on the maps where specific acts of violence have occurred-an understanding of which implicitly guides their mobility decisions. This mapping exercise catalyzes an explicit community process. Typically, one step is the girls' decision to walk in groups to school. In one community, a safety commission has been set up.

For further information, please contact Population Council consultant Angel del Valle, adelvalle@popcouncil.org.

\section{A community contract that rejects violence: Tostan, West Africa}

Tostan has pioneered a form of dialogue with communities to reject female genital mutilation (FGM) and, more recently, child marriage. While this program does not yet measure results at the level of the girl, it has catalyzed community efforts to eliminate serious forms of abuse. A principled strategy by which this is accomplished is designed to accelerate the abandonment of FGM. Among villages that participated in the Tostan program, prevalence of FGM reportedly dropped by $70 \%$ versus $40 \%$ in control villages (results based on reports of "key informants" not girls). This strategy is founded on the understanding that to change social norms requires reaching a critical mass of community members, because FGM and child marriage are related to a commonly perceived standard of girls who are considered decent for marriage. Tostan's approach uses qualitative evaluation to improve the strength of program delivery. ${ }^{39}$

For further information, please contact Gannon Gillespie, Director of Strategic Development, Tostan; gannongillespie@tostan.org; 212-299-1156.

The Safe Cities program: The Association for the Development and Enhancement of Women, Egypt

The Safe Cities program, now being rolled out in various Cairo neighborhoods, aims to reduce sexual harassment and sexual violence against girls and women that is being committed in urban public spaces (neighborhood squares, alleys, abandoned buildings, construction sites). Sexual harassment is conceived as impeding girls and women from carrying out their domestic responsibilities, accessing services and jobs, and developing their skills, and creating interference in getting to and from schools and a lack of safety in public parks. The project will work with at-risk women and girls, local authorities, other grassroots groups, and the media to create greater access and safety in public spaces.

For further information, contact Iman Bibars, ibibars@ASHOKA.ORG, at the Association for the Development and Enhancement of Women.

Paraprofessional Social Work Training Program, International Rescue Committee (IRC), Somali Region of Ethiopia

The Paraprofessional Social Work training program reaches girls and women living in hard-to-reach districts in the Somali region of Ethiopia. This UNICEF-supported program brings two community members from each village 


\section{MORE SPECIFIC MEASURES TO AVOID EXISTING POTENTIAL THREATS}

- Safety nets

- Someone to turn to in case of an emergency

- Place to spend the night in an emergency

- Someone from whom to borrow money in an emergency

- Self esteem/sense of agency/aspirations

- Personal documentation/recognition of membership in the community

- Context-specific knowledge of services (placement, hours, evidence of registration)

- Specific knowledge of risky people, seasons, events

- Specific safety/emergency plans

Source: Erulkar, Annabel S.; Muthengi, Eunice. Evaluation of Berhane Hewan: A program to delay child marriage in rural Ethiopia. International Perspectives on Sexual and Reproductive Health 35(1): 6-14 . Erulkar, Annabel S.; Mekbib, Tekle-Ab; Tegegne, Mesfin. Biruh Tesfa: Creating a 'Bright Future' for migrant girls in urban areas of Ethiopia. Promoting Healthy, Safe, and Productive Transitions to Adulthood Brief. 2008 Adolescent and Youth Sexual and Reproductive Health: Charting Directions for a Second Generation of Programming-Background Documents for the Meeting, pp. 77-89 2003. Bruce, Judith; Hallman, Kelly. Reaching the girls left behind. Gender and Development 16(2): 227-245. 2008. Hallman, Kelly. Program.

(one female/one male) to be trained over the course of one year as social workers. The social workers come from villages where conflict is pervasive and it is likely girls suffer from high levels of sexual, psychological, and physical violence as a result of the conflict and traditional Somali cultural norms. Over the course of one year, as a part of a larger social work program, IRC provides the students with a series of four one-week trainings on responses to gender-based violence. Topics include case management, providing general psychosocial support, active listening, confidentiality, and referrals. The social work students convene in the regional capital each quarter for training and spend the rest of their time in the field practicing their new skills. This psychosocial training program is complemented by a training program for justice, health, and legal service providers to build the capacity of those in other sectors to respond to survivors of violence. The next phase of this project will include developing a standard operating procedure for service providers, to establish the roles and responsibilities of each sector, outline a referral pathway, and streamline the response process. This program allows girls and women access to support, whether they have experienced violence or the threat of violence, or need a social connection. In a nonconflict setting with easier to access populations, this intervention could be more comprehensive, however this form of the model can be used in conflict areas where humanitarian agencies have difficulty accessing the target population.

For further information, contact Jody Myrum at Jody.Myrum@nike.com.

\section{Growing Up Safe and Healthy}

(SAFE): Reducing the gender equality gap through gender-based violence prevention messages in Bangladesh

The Growing Up Safe and Healthy (SAFE) project aims to promote gender equity for 10-17-year-old unmarried and married girls living in urban slums in Bangladesh. SAFE addresses ado- lescent girls' heightened vulnerability and marginalization by targeting child marriage and gender-based violence issues through service-delivery programs that raise awareness of violations of women's rights through a combination of sexual and reproductive health messages (bodily integrity, issues of consent and choice, and promoting overall self-determination of their lives). SAFE also creates strong links and networks between legal services and reproductive and sexual health service providers located near the slums, human rights and women's rights advocates, research organizations, and Bangladesh's Ministry of Women and Children's Affairs. At the legal and health-service centers, SAFE employees instruct girls and women on how to protect themselves against sexual and reproductive health risks and gender-based violence.

For further information, contact Sajeda Amin at samin@popcouncil.org.

\section{Apne Aap: Eradicating sex-} trafficking in India

Apne Aap, founded by investigative journalist Ruchira Gupta, is a grassroots organization in Mumbai, India (with other program sites in Bhiwandi, Bihar, Delhi, and West Bengal) that reaches the most isolated and at-risk women and children who are trapped in or are at-risk of prostitution in India's red-light areas and slums. Apne Aap mobilizes and mentors community-based groups of trafficked and vulnerable girls and women so they can empower one another. Apne Aap provides a safe space and opportunities for legal, educational, and livelihood training to girls and women so they can develop the skills and abilities to resist traffickers. The organization has reached over 10,000 women and girls, and of these, 812 girls are in regular schools, 1,200 women have formed small business cooperatives known as self-help groups, and 3,042 women have submitted a petition to Indian Parliament asking for a change in the anti-trafficking law, Immoral Trafficking Prevention Act (ITPA), to punish buyers and protect women and girls.

For further information, please contact Zoe Young at zoe@apneaap.org. 
It's All One Curriculum: A unified approach to sexuality, gender, HIV, and human rights education

It's All One Curriculum is a resource kit for developing a unified curriculum on sexuality, gender, HIV, and human rights. It is based on global research on risks to sexual health. It responds to the MilIennium Development Goals and related policy mandates and brings a muchneeded fresh and practical approach to educating young people in a diverse and rapidly changing world. Specifically, It's All One Curriculum enables educators and policymakers to address not only the individual determinants of young people's sexual and reproductive health, but also the distinctive needs of different subsets-girls, boys, gay and lesbian adolescents. It's All One Curriculum was developed by an international group of experts to enable young people to enjoy-and advocate for their rights todignity, equality, and healthy, responsible, and satisfying sexual lives.

To download a PDF of It's All One Curriculum in English, French, or Spanish, or to order a hard copy of the kit, go to www.ItsAllOne.org.

\section{Other resources:}

Amin, Sajeda and Althea D. Anderson. May 2011. "Addressing sexual and genderbased violence (SGBV) against adolescent girls," Promoting Healthy, Safe, and Productive Transitions to Adulthood Brief, no. 38, <http://www.popcouncil. org/pdfs/TABriefs/38_SGBV.pdf>.

Krause-Vilmar, Jina. 2011. Preventing Gender-based Violence, Building Livelihoods: Guidance and Tools for Improved Programming. New York: Women's Refugee Commission. <womensrefugeecommission. org/resources/doc_download/798preventing-gender-based-violencebuilding-livelihoods-guidance-and-toolsfor-improved-programming>.

Ricardo, C., G. Barker, and M. Eads. 2012, in press. Engaging Boys and Young Men in the Prevention of Sexual violence: A Systematic and Global Review of Evaluated Interventions. SVRI and Promundo.

Together for Girls is a global public-private partnership dedicated to eliminating sexual violence against girls. The partnership focuses on three pillars: conducting and supporting national surveys on the magnitude and impact of violence against children, particularly focused on sexual violence against girls; supporting coordinated program actions in response to the data; and leading global advocacy and public awareness efforts to draw attention to the problem and promote evidence-based solutions. Please contact Together for Girls through Jennifer Kim, jen@togetherforgirls.org. The partnership's website is $<w w w$. togetherforgirls.org>.

\section{NOTES}

1 Ellesberg, M. and L. Heise. Researching Violence against Women: A Practical Guide for Researchers and Activists. Washington, DC: World Health Organization, 2005.

2 "Violence against children in Tanzania: Findings from a national survey 2009." United Nations Children's Fund, US Centers for Disease Control and Prevention, Muhimbili University of Health and Allied Sciences, August 2011.

3 Reza, Avid et al. "Sexual violence and its health consequences for female children in Swaziland: A cluster survey study." US Centers for Disease Control and Prevention, 2009.

4 See note 2.

5 Gray, Ron, Fred Nalugoda, David Serwadda, and Maria Wawer. "Marriage and HIV risk: Data from Rakai, Uganda." Paper presented at Exploring the Risks of HIV/AIDS Within the Context of Marriage. Population Council, New York, 10 November 2004.

6 Jejeebhoy, Shireen. "The adverse health and social outcomes of sexual coercion: Experiences of young women in developing countries." Population Council, 2004.

7 Garcia-Moreno, Claudia. "Putting women first: Ethical and safety recommendations for research on domestic violence against women." Department of Gender and Women's Health, World Health Organization. Geneva, Switzerland, 2001.

8 "Violence against children in Tanzania: Findings from a national survey 2009." United Nations Children's Fund, US Centers for Disease Control and Prevention, Muhimbili University of Health and Allied Sciences, August 2011.

9 For a fuller discussion, see also Hallman 2004 (South Africa); Erulkar et al. 2004a; 2004b (Ethiopia); Amin et al. 2002 (Bangladesh); Haberland et al. 2003 (India); UNICEF and Population Council 2002; and Alexander et al. 2006. The National Surveys of Adoles- cence conducted by the Guttmacher Institute and country partners in Burkina Faso, Ghana, Malawi, and Uganda revealed data on density of friendship networks, showing that across all groups (rural/urban, schooling achievement), boys have more close friends on average than girls. (A. Biddlecom 2008 correspondence with researcher.)

10 Haiti Safety Exercise. Maternowska, Catherine and Ghislaine Ouedraogo. 2010. "Haiti Adolescent Girls NetworkEspas Pa Mwen: A Report on Adolescent Girl Programming in Haiti."

11 For a fuller discussion, see also Hallman 2004 (South Africa); Erulkar et al. 2004a, 2004b (Ethiopia); Amin et al. 2002 (Bangladesh); Haberland et al. 2003 (India); UNICEF and Population Council 2002; and Alexander et al. 2006. The National Surveys of Adolescence conducted by the Guttmacher Institute and country partners in Burkina Faso, Ghana Malawi, and Uganda revealed data on density of friendship networks, showing that across all groups (rural/urban, schooling achievement), boys have more close friends on average than girls. (A. Biddlecom 2008 correspondence with researcher.)

12 Population Council team (Bruce, Austrian) developed a safety scan that could be used in workshop contexts to begin to define the parameters of safety by day, week, situation. An introduction to these can be found in <www.popcouncil. org/2010AdolGirlsToolkit>.

13 Simbaya, Joseph and Martha Brady. "Understanding adolescent girls' protection strategies against HIV: An exploratory study in urban Lusaka. Population Council, 2009.

14 Campbell et al. 2002; Gazaramian et al. 1995; Goldin 1996; Murphy et al. 2001; Zierler et al. 1991.

15 Reza, Avid et al. "Sexual violence and its health consequences for female children in Swaziland: A cluster survey study." Center for Disease Control, 2009.

16 Source: 2007 Liberia DHSS and 2008-09 Liberia Coverage Exercise with pilot coverage exercise data from four community-based programs. Tabulations by Adam Weiner.

17 Hallman, Kelly. "Adolescent social exclusion: The gendering of HIV risk in KwaZulu-Natal, South Africa." Population Council, 2010.

18 Bruce, Judith and Kelly Hallman. 2008. "Reaching the girls left behind," Gender \& Development 16(2): 227-245. 
19 Lloyd, Cynthia. "Growing Up Global: The Changing Transitions to Adulthood in Developing Countries." National Academies Press, 2005.

20 Breiding, Matthew J. and Avid Reza. "Risk factors associated with sexual violence towards girls in Swaziland." Bulletin of the World Health Organization 2011;89:203-210.

21 Breiding, Matthew J. and Avid Reza. "Risk factors associated with sexual violence towards girls in Swaziland." Bulletin of the World Health Organization 2011;89:203210. (2) Lesniak, L.P. "Penetrating the conspiracy of silence: Identifying the family at risk for incest." Family Community Health 1993;16:66-76. (3) Ajuwon, A.J., A. Olaleye, B. Faromoju, and O. Ladipo. "Sexual behavior and experience of sexual coercion among secondary school students in three states in North Eastern Nigeria." BMC Public Health 2006;6:310. doi:10.1186/1471-2458-6310 PMID:17187685. (4) Boney-McCoy, $\mathrm{S}$. and D. Finkelhor. "Prior victimization: A risk factor for child sexual abuse and for PTSD-related symptomatology among sexually abused youth." Child Abuse \& Neglect 1995;19:1401-21. doi:10.1016/0145-2134(95)00104-9 PMID:8777692).

22 Hallman, K. et al. June 6, 2007. "Social capital, socioeconomic aspirations, and HIV risk behaviors among poor South African youth." Poster presented at 3rd South African AIDS Conference, Durban, South Africa.

23 "The Adolescent Experience In-Depth: Using Data to Identify and Reach the Most Vulnerable Young People: Benin 2006." New York: Population Council, 2009 (Page 49).

24 “The Adolescent Experience In-Depth: Using Data to Identify and Reach the Most Vulnerable Young People: Haiti 2005/06." New York: Population Council, 2009 (Page 49).

25 Erulkar, Annabel. "Adolescent Life in Low Income and Slum Areas of Addis Ababa Ethiopia" Population Council, 2004.

26 Bruce, Judith and Kelly Hallman. 2008. "Reaching the girls left behind," Gender \& Development 16(2): 227-245.

27 Liberia Institute of Statistics and Geo-Information Services (LISGIS). 2009. 2008 Population and Housing Census Final Results. Monrovia: LISGIS. Lloyd, Cynthia B. (ed.). 2005. Growing Up Global: The Changing Transitions to Adulthood in Developing Countries. Washington, DC: National Academies Press. Mekbib, T., A.
Erulkar, and F. Belete. 2005. "Who are the targets of youth programs: Results of a capacity building exercise in Ethiopia," Ethiopian Journal of Health Development 19(1): 60-62. Macro International. 2011. MEASURE DHS STATcompiler. <http://www.measuredhs.com>. Accessed 8 March 2011. Population Council. 2006. How to Conduct a Coverage Exercise: A Rapid Assessment Tool for Programs and Services. New York: Population Council.Population Council. 2009. The Adolescent Experience In-Depth: Using Data to Identify and Reach the Most Vulnerable Young People (Malawi 2004). New York: Population Council. Population Division of the Department of Economic and Social Affairs of the United Nations Secretariat (UNESA), World Population Prospects: The 2008 Revision, <http:// esa.un.org/unpp>. Accessed 2 February 2011. Weiner, Adam. 2010. "Geographic variations in inequities in access to sexual and reproductive health services," Studies in Family Planning 41(2): 134-138.

28 Hallman 2004 personal communication.

29 Conceptualized by Judith Bruce and Karen Austrian. Published by Austrian, K. and D. Ghati. Girl-Centered Program Design: A Toolkit to Develop, Strengthen and Expand Adolescent Girls Programs. New York: Population Council, 2010.

30 For review of the importance of social capital see: Bruce, Judith and Kelly Hallman. 2008. "Reaching the girls left behind," Gender \& Development 16(2): 227-245. For description of the steps involved in creating a girl platforms see Austrian, K. and D. Ghati. Girl Centered Program Design: A Toolkit to Develop, Strengthen and Expand Adolescent Girls Programs. New York: Population Council, 2010.

31 Catino, Jennifer, Alejandra Colom, and Marta Julia Ruiz. 2011. "Equipping Mayan girls to improve their lives," Transitions to Adulthood Brief no. 5, <http://www.popcouncil.org/pdfs/ TABriefs/05_MayanGirls.pdf>; Erulkar, Annabel, Belaynesh Semunegus, and Gebeyehu Mekonnen. 2011. "Biruh Tesfa provides domestic workers, orphans, and migrants in urban Ethiopia with social support, HIV education, and skills," Transitions to Adulthood Brief no. 21, <http://www.popcouncil.org/pdfs/ TABriefs/21_BiruhTesfa.pdf $>$.

32 Dupas, Pascaline. 2010. Do Teenagers Respond to HIV Risk Information? Evidence from a Field Experiment in Kenya. Unpublished Manuscript, UCLA.
33 Jody Myrum, Nike Foundation, personal communication.

34 Adolescent Girls Legal Defense Fund. Forthcoming. "Equality Now Adolescent Girls Legal Defense Fund Learning from Cases of Girls' Rights." For more details, contact Mehr Qureshi at mqureshi@ equalitynow.org.

35 Erulkar, Annabel. "Adolescent life in low income and slum areas of Addis Ababa Ethiopia." Population Council, 2004. Hallman, K. et al. "Social capital, socioeconomic aspirations, and HIV risk behaviors among poor South African youth," poster presented at 3rd South African AIDS Conference, Durban, South Africa, 6 June 2007.

36 Erulkar, Annabel S. and Eunice Muthengi. 2009. "Evaluation of Berhane Hewan: A program to delay child marriage in rural Ethiopia." International Perspectives on Sexual and Reproductive Health 35(1): 6-14.

37 CRISP Program in KwaZulu Natal.

38 Erulkar, Annabel. "Biruh Tesfa (Bright Future) Program Provides Domestic Workers, Orphans \& Migrants in Urban Ethiopia with Social Support, HIV Education \& Skills." Population Council.

39 Diop, Nafissatou, Amadou Morwau, and Helene Benga. 2008. "Evaluation of the long-term impact of the TOSTAN programme on the abandonment of FGM and early marriage: Results from a qualitative study in Senegal," FRONTIERS Final Report. New York: Population Council.

\section{ACKNOWLEDGMENTS}

This Review was written by Judith Bruce, Senior Associate and Policy Analyst at the Population Council. This Review has benefited immeasurably from the input of many. The author gratefully acknowledges the following colleagues for their invaluable substantive feedback and technical contributions: Sajeda Amin, Farida Deif, Dina Deligiorgis, Lori Heise, Heidi Lehmann, Michele Moloney-Kitts, Jody Myrum, and Avid Reza. Special thanks go to Nicole Ippoliti, Sura Rosenthal, Gina Duclayan, and Christina Tse for their tireless editorial and production support. The author alone is responsible for any errors or omissions. Finally, the author would like to acknowledge and thank the Population Council, the Nike Foundation, the Packard Foundation and the UN Adolescent Girls Task Force for their partnership and support, without which these Program Reviews would not be possible. 


\section{Population Council}

The Population Council confronts critical health and development issues-from stopping the spread of HIV to improving reproductive health and ensuring that young people lead full and productive lives. Through biomedical, social science, and public health research in 50 countries, the Council works with our partners to deliver solutions that lead to more effective policies, programs, and technologies that improve lives around the world. Established in 1952 and headquartered in New York, the Council is a nongovernmental, nonprofit organization governed by an international board of trustees.

www.popcouncil.org 